\title{
Fifteen years of progress in understanding frailty and health in aging
}

Kenneth Rockwood ${ }^{1 *}$ and Susan E. Howlett ${ }^{1,2}$

\begin{abstract}
The notion of frailty has evolved for more than 15 years. Although there is no consensus definition, frailty reflects a state of increased vulnerability to adverse health outcomes for individuals of the same chronological age. Two commonly used clinical tools, the frailty index and the frailty phenotype, both measure health-related deficits. The frailty index is a ratio of the number of deficits that an individual has accumulated divided by all deficits measured, whereas the phenotype specifies frailty as represented by poor performance in three of five criteria (i.e., weight loss, exhaustion, weakness, slowness, lack of activity). From human studies, animal models of both approaches have been developed and are beginning to shed light on mechanisms underlying frailty, the influence of frailty on disease expression, and new interventions to attenuate frailty. Currently, back-translation to humans is occurring. As we start to understand subcellular mechanisms involved in damage and repair as well as their response to treatment, we will begin to understand the molecular basis of aging and, thus, of frailty.
\end{abstract}

Keywords: Frailty index, Frailty phenotype, Deficit index, Deficit accumulation, Aging, biomarkers, Senescence, senolytics

\section{Background}

A 1994 paper summarized frailty as "an evolving concept" [1] and, to some extent, this remains true. Herein, we summarize progress in research on frailty over the last 15 years. We consider one of the first uses of the term and contrast it with the two main approaches now used as determined by an extensive literature search on iterative uses of frailty, focusing on definitions, animal models, prevention, and treatment. Classic papers or reviews were prioritized where useful.

\section{Our still evolving understanding of frailty}

Research regarding frailty saw the beginning of a new era approximately 15 years ago. Prior to 2001, a PubMed search for the word 'frailty', when it was defined at all, was defined by its statistical meaning. To statisticians, frailty had been generalized to quantify variability in the risk of adverse outcomes for people with the same degree of exposure, and thus its origin was rooted in demography [2]. Unmeasured heterogeneity of aging rates

\footnotetext{
* Correspondence: kenneth.rockwood@dal.ca

${ }^{1}$ Geriatric Medicine, Department of Medicine, Dalhousie University, Halifax, NS, Canada

Full list of author information is available at the end of the article
}

was invoked to explain the apparent paradox that, at extreme old age, the risk of death fell. The reasoning was that, prior to the eleventh decade, mortality risk was averaged across people with varying intrinsic rates of aging; however, past this age, only very slow agers remained alive, and thus the mortality rate appeared to slow. In 2001, two distinct clinical approaches to understanding frailty were elaborated $[3,4]$. One of these approaches argues that the increased risk of frailty could be captured as a characteristic syndrome, understood as the loss of strength, speed, or weight, a sense of lack of energy, or the inability to perform demanding activities such as gardening and heavy housework. Combinations of at least three of these features are held to define a 'frailty phenotype' [3]. Conversely, the other clinical approach (developed by our team) defines frailty not as a specific syndrome, but rather as a state of age-related deficit accumulation, quantified in a 'frailty index', itself representing the ratio of deficits present to deficits evaluated for a given individual [4]. To the consternation of those who argue that progress requires a majority consensus, both operational definitions still stand. (Our view is that progress requires an approach that can resolve the contradictions between the two). 
Nevertheless, despite some contradictions - chiefly regarding which individuals are classified as frail, and in their abilities to stage frailty and predict mortality - the two approaches to frailty have much in common [5]. Each identifies people at increased risk, albeit often not the same people. They have both been operationalized for use in administrative databases $[6$, 7], with one being used routinely in primary care for that purpose [8]. Additionally, both approaches are widely used [9], including in special populations such as people living with HIV/AIDS [10], as well as in multi-omics analyses of frailty $[11,12]$ or to define risk in invasive or toxic healthcare interventions [13, 14]. Finally, they have both been used to evaluate the association of frailty with the subsequent onset of other well-defined, late-onset illnesses, including dementia [15]. Both approaches are also used with substantial modification $[16,17]$.

In short, the operationalization of frailty, even with two competing approaches, has allowed a wide range of studies to be undertaken in older adults at increased risk. Similarly, the ability to quantify frailty in people is a major development that has led to recent advances in our understanding of the biology of frailty.

\section{Biological models and mechanisms of frailty}

Whether measured as a phenotype or by deficit accumulation, frailty has demonstrable biological underpinnings that can be studied with animal models [18]. Both the frailty index and frailty phenotype approaches have been adapted for use in naturally aging animals. The first mouse frailty index was developed in 2012, where scores that deviated from average values in healthy adults for blood work, activity levels, body composition, and hemodynamics were counted as deficits [19]. This was followed by observational 'clinical' frailty index tools developed for use in both mice and rats $[20,21]$. The frailty phenotype approach has also been tailored for use in aging rodents [22]. Together, these powerful new tools have the potential to help translate advances in basic science into meaningful clinical interventions.

There is strong evidence that aging mice can model frailty in humans, at least with respect to the frailty index. Properties of the frailty index (e.g., ranges of frailty scores, rates of deficit accumulation, and submaximal limits to frailty) are similar in mice and people across the life course [23]. In addition, naturally aging female mice have higher frailty scores than males, as seen in clinical studies [24]. Mouse models have also inspired new approaches to frailty assessment in people. For instance a frailty index based on routine blood work and hemodynamic measures (the FI-LAB), which was originally developed for use in mice [19], has been shown to predict mortality in people [25]. This approach has also provided a sound basis for understanding that frailty can be seen across the life course, with determinants that arise prior to clinically detectable deficits [26, 27]. Other translational work has studied epigenetic changes - characterized as the DNA methylation clock - both in frailty as a deficit accumulation [28] and in the frailty phenotype [29].

Advances in understanding subcellular mechanisms of damage and repair are providing new knowledge on the molecular basis of aging and, thus, of frailty. Animal models are providing insights on the physiologic mechanisms of frailty, the influence of frailty on disease, and interventions to mitigate frailty. For example, pro-inflammatory cytokine levels are positively correlated with frailty in aging mice in a sex-specific fashion, indicating a critical role for inflammation in frailty [24]. Signs of cardiac aging, including myocardial hypertrophy and contractile dysfunction, are also graded by the frailty index score [30], suggesting that heterogeneity in overall health can help explain heterogeneity in cardiac aging. The mouse frailty index also declines in response to interventions designed to extend lifespan (e.g., resveratrol treatment, caloric restriction) and health-span (e.g., angiotensin converting enzyme inhibitors) of mice [31,32].

Various hallmarks of aging appear to be susceptible to interventions. One such intervention involves a new therapeutic class of senolytic drugs, which selectively induce apoptosis in senescent cells and thereby reduce secretion of deleterious senescence-associated cytokines and related damaging agents. A recent report suggested that intermittent oral administration of a 'senolytic cocktail' can selectively eliminate senescent cells, and thereby decrease their secretion of frailty-related proinflammatory cytokines [33]. Drugs that can counter the senescence-associated secretory phenotype (known as SASP) include metformin, which is now in human trials. Further, signaling between the mitochondrial and nuclear genomes to offer adaptive responses during aging appear to be highly conserved, offering additional treatment targets [34].

Nevertheless, despite the shared multiplicity of uses, it has been expressed that the two approaches to frailty have distinct purposes, or contexts, in which they are most likely to be feasible, and should therefore be employed in that regard [35]. Another view is that real progress requires treatment and that regulatory approval of treatment requires a clear operational definition, arguing that the possibility of regulatory approval would be a trumping virtue. Conversely, it is sobering to note that, in a review of frailty in acute care [9], the most common operational definition was none at all.

A major sign of the growing importance attached to frailty and its widespread use is the recent pushback that has been observed - many older people do not like the term [36]. Therefore, the use of alternative terms have been proposed, such as 'resilience', yet this has also 
proved a controversial definition [37]. Our view is that we should not set aside the progress made in a formal quantitative understanding of frailty in order to engage in a debate about semantics. Indeed, there are formal approaches to resilience (in engineering disciplines), each with a considerable mathematical apparatus that can be employed [37]; adapting insights from quantitative disciplines has been done in relation to frailty [27].

Equally concerning is the occasional sense that frailty screening is being promoted as a means to root out the undeserving elderly ill - screening for frailty to prevent admission of those who might otherwise 'block' hospital beds rather than to improve care by, for example, making routine care less hazardous. The goal of defining frailty is not simply to operationalize risk. Instead, for frailty assessment to help patients, information from it must inform the care plan. This has been seen, for example, in orthogeriatrics, where the dual geriatric assessment goals of evaluation and management have proven to benefit both lifespan and health-span [38]. Finally, both views of frailty have strong social determinants and consequences [39]; their interaction itself faces controversy in how the social determinants of health are operationalized. Progress in this regard, as with frailty itself, can be demonstrated despite the elusiveness of a final consensus on how to define the social determinants of health.

\section{Conclusions}

The concept of frailty aims to address the considerable heterogeneity in health status of people as they age. Two operational approaches are in routine use and await overarching research to explain the ways in which they differ. Nevertheless, they have much in common, both identifying older adults at greater risk.

Now that links of frailty to aging mechanisms are becoming available, a better method to assay heterogeneity in risk may emerge, possibly even accompanied by new therapeutic approaches that tackle the fundamental processes of aging. However that may pan out, variable impacts of aging that give rise to frailty will continue to involve a strong set of social determinants. The important challenge posed by older people with multiple and interacting medical and social problems will remain to be addressed, regardless of the words used to describe them. Therefore, all knowledge on frailty will be essential.

\section{Acknowledgements}

Not applicable.

\section{Funding}

SEH is funded by the Canadian Institutes for Health Research grants (MOP 97973 and PGT 155961). KR is funded by the Canadian Institutes for Health Research grant MOP 209888.
Availability of data and materials

Not applicable.

\section{Authors' contributions}

KR and SEH both wrote the manuscript, and read and approved the final version.

Ethics approval and consent to participate

Not applicable.

\section{Consent for publication}

Not applicable.

\section{Competing interests}

Through Dalhousie University, KR has asserted copyright of the Clinical Frailty Scale, which is made freely available for research, educational and not-forprofit healthcare use. Users are asked to agree to not change or commercialize it. He founded and is President and Chief Science Officer of DGl Clinical, which has contracts with Shire, Roche, Otsuka, and Hollister for individualized outcome measurement and data analytics.

\section{Publisher's Note}

Springer Nature remains neutral with regard to jurisdictional claims in published maps and institutional affiliations.

\section{Author details}

'Geriatric Medicine, Department of Medicine, Dalhousie University, Halifax, NS, Canada. ${ }^{2}$ Department of Pharmacology, Dalhousie University, Halifax, NS, Canada.

Received: 19 November 2018 Accepted: 19 November 2018

Published online: 27 November 2018

References

1. Rockwood K, Fox RA, Stolee P, Robertson D, Beattie BL. Frailty in elderly people: an evolving concept. CMAJ. 1994;150:489-95.

2. Vaupel JW, Manton KG, Stallard E. The impact of heterogeneity in individual frailty on the dynamics of mortality. Demography. 1979;16:439-54.

3. Fried LP, Tangen CM, Walston J, Newman AB, Hirsch C, Gottdiener J, Seeman T, Tracy R, Kop WJ, Burke G, McBurnie MA. Cardiovascular Health Study Collaborative Research Group. Frailty in older adults: evidence for a phenotype. J Gerontol A Biol Sci Med Sci. 2001;56:M146-56.

4. Mitnitski AB, Mogilner AJ, Rockwood K. Accumulation of deficit as a proxy measure of aging. Sci World J. 2001;1:323-36.

5. Theou O, Brothers TD, Peña FG, Mitnitski A, Rockwood K. Identifying common characteristics of frailty across seven scales. J Am Geriatr Soc. 2014:62:901-6.

6. Segal JB, Chang H-Y, Du Y, Walston JD, Carlson MC, Varadhan R. Development of a claims-based frailty indicator anchored to a wellestablished frailty phenotype. Med Care. 2017;55:716-22 Erratum in: Med Care. 2017:55:1062.

7. Kim DH, Glynn RJ, Avorn J, Lipsitz LA, Rockwood K, Pawar A, Schneeweiss S. Validation of a claims-based frailty index against physical performance and adverse health outcomes in the Health and Retirement Study. J Gerontol A Biol Sci Med Sci. 2018; https://doi.org/ 10.1093/gerona/gly197. Ahead of print.

8. Clegg A, Bates C, Young J, Ryan R, Nichols L, Ann Teale E, Mohammed MA, Parry J, Marshall T. Development and validation of an electronic frailty index using routineprimary care electronic health record data. Age Ageing. 2016; 45(3):353-60 Erratum in: Age Ageing. 2018;47(2):319.

9. Theou O, Squires E, Mallery K, Lee JS, Fay S, Goldstein J, Armstrong JJ, Rockwood K. What do we know about frailty in the acute care setting? A scoping review. BMC Geriatr. 2018;18:139.

10. Greene M, Justice AC, Covinsky KE. Assessment of geriatric syndromes and physical function in people living with HIV. Virulence. 2017;8:586-98.

11. Erusalimsky JD, Grillari J, Grun T, Jansen-Duerr P, Lippi G, Sinclair AJ, Tegnér J, Viña J, Durrance-Bagale A, Miñambres R, Viegas M, Rodríguez-Mañas L. FRAILOMIC Consortium. In search of 'omics'-based biomarkers to predict risk of frailty and its consequences in older individuals: The FRAILOMIC Initiative. Gerontology. 2016;62:182-90. 
12. Livshits G, Malkin I, Bowyer RCE, Verdi S, Bell J, Menni C, Williams FMK, Steves CJ. Multi-OMICS analyses of frailty and common widespread pain suggest involvement of shared neurological pathways. Pain. 2018; https:// doi.org/10.1097/j.pain.0000000000001364. Ahead of print.

13. Ethun CG, Bilen MA, Jani AB, Maithel SK, Ogan K, Master VA. Frailty and cancer: implications for oncology surgery, medical oncology. and radiation oncology. CA Cancer J Clin. 2017;67:362-77.

14. Montgomery $\mathrm{CL}$, Rolfson DB, Bagshaw SM. Frailty and the association between long-term recovery after intensive care unit admission. Crit Care Clin. 2018;34:527-47.

15. Wallace L, Theou O, Rockwood K, Andrew MK. Relationship between frailty and Alzheimer's disease biomarkers: a scoping review. Alzheimers Dement 2018;10:394-401.

16. Theou O, Cann L, Blodgett J, Wallace LM, Brothers TD, Rockwood K. Modifications to the frailty phenotype criteria: systematic review of the current literature and investigation of 262 frailty phenotypes in the Survey of Health, Ageing, and Retirement in Europe. Ageing Res Rev. 2015;21:78-94.

17. Wang J, Zou Y, Zhao J, Schneider DB, Yang Y, Ma Y, Huang B, Yuan D. The impact of frailty on outcomes of elderly patients after major vascular surgery: a systematic review and meta-analysis. Eur J Vasc Endovasc Surg. 2018:56:591-602.

18. Howlett SE, Rockwood K. Ageing: develop models of frailty. Nature. 2014; 512:253.

19. Parks RJ, Fares E, Macdonald JK, Ernst MC, Sinal CJ, Rockwood K, Howlett SE. A procedure for creating a frailty index based on deficit accumulation in aging mice. J Gerontol A Biol Sci Med Sci. 2012;67:217-27.

20. Whitehead JC, Hildebrand BA, Sun M, Rockwood MR, Rose RA, Rockwood K, Howlett SE. A clinical frailty index in aging mice: comparisons with frailty index data in humans. J Gerontol A Biol Sci Med Sci. 2014;69:621-32.

21. Yorke A, Kane AE, Hancock Friesen CL, Howlett SE, O'Blenes S. Development of a rat clinical frailty index. J Gerontol A Biol Sci Med Sci. 2017;72:897-903.

22. Kane AE, Hilmer SN, Mach J, Mitchell SJ, de Cabo R, Howlett SE. Animal models of frailty: current applications in clinical research. Clin Interv Aging. 2016;11:1519-29.

23. Rockwood K, Blodgett JM, Theou O, Sun MH, Feridooni HA, Mitnitski A, Rose RA, Godin J, Gregson E, Howlett SE. A frailty index based on deficit accumulation quantifies mortality risk in humans and in mice. Sci Rep. 2017; 7:43068.

24. Kane AE, Keller KM, Heinze-Milne S, Grandy SA, Howlett SE. A murine frailty index based on clinical and laboratory measurements: links between frailty and pro-inflammatory cytokines differ in a sex-specific manner. J Gerontol A Biol Sci Med Sci. 2018; https://doi.org/10.1093/gerona/gly117. Ahead of print.

25. Howlett SE, Rockwood MR, Mitnitski A, Rockwood K. Standard laboratory tests to identify older adults at increased risk of death. BMC Med. 2014:12:171

26. Blodgett JM, Theou O, Howlett SE, Rockwood K. A frailty index from common clinical and laboratory tests predicts increased risk of death across the life course. Geroscience. 2017; https://doi.org/10.1007/s11357-017-9993-7.

27. Rutenberg AD, Mitnitski AB, Farrell SG, Rockwood K. Unifying aging and frailty through complex dynamical networks. Exp Gerontol. 2018; 107:126-9.

28. Kim S, Wyckoff J, Morris AT, Succop A, Avery A, Duncan GE, Michal Jazwinski S. DNA methylation associated with healthy aging of elderly twins. Geroscience. 2018; https://doi.org/10.1007/s11357-018-0040-0. Ahead of print.

29. Gale CR, Marioni RE, Harris SE, Starr JM, Deary IJ. DNA methylation and the epigenetic clock in relation to physical frailty in older people: the Lothian Birth Cohort 1936. Clin Epigenetics. 2018;10:101.

30. Feridooni HA, Kane AE, Ayaz O, Boroumandi A, Polidovitch N, Tsushima RG, Rose RA, Howlett SE. The impact of age and frailty on ventricular structure and function in C57BL/6J mice. J Physiol. 2017;595:3721-42.

31. Kane AE, Hilmer SN, Boyer D, Gavin K, Nines D, Howlett SE, de Cabo R, Mitchell SJ. Impact of longevity interventions on a validated mouse clinical frailty index. J Gerontol A Biol Sci Med Sci. 2016;71:333-9.

32. Keller K, Kane A, Heinze-Milne S, Grandy SA, Howlett SE. Chronic treatment with the ACE inhibitor enalapril attenuates the development of frailty and differentially modifies pro- and anti-inflammatory cytokines in aging male and female C57BL/6 mice. J Gerontol A Biol Sci Med Sci. 2018; https://doi. org/10.1093/gerona/gly219. Ahead of print.
33. Xu M, Pirtskhalava T, Farr JN, Weigand BM, Palmer AK, Weivoda MM, Inman CL, Ogrodnik MB, Hachfeld CM, Fraser DG, Onken JL, Johnson KO, Verzosa GC, Langhi LGP, Weigl M, Giorgadze N, LeBrasseur NK, Miller JD, Jurk D, Singh RJ, Allison DB, Ejima K, Hubbard GB, Ikeno Y, Cubro H, Garovic VD, Hou X, Weroha SJ, Robbins PD, Niedernhofer LJ, Khosla S, Tchkonia T, Kirkland JL. Senolytics improve physical function and increase lifespan in old age. Nat Med. 2018;24:1246-56.

34. Jazwinski SM, Jiang JC, Kim S. Adaptation to metabolic dysfunction during aging: making the best of a bad situation. Exp Gerontol. 2018;107:87-90.

35. Walston JD, Bandeen-Roche K. Frailty: a tale of two concepts. BMC Med. 2015;13:185

36. Mudge AM, Hubbard RE. Frailty: mind the gap. Age Ageing. 2017; https:// doi.org/10.1093/ageing/afx193. Ahead of print.

37. Kuchel GA. Frailty and Resilience as Outcome Measures in Clinical Trials and Geriatric Care: Are We Getting Any Closer? J Am Geriatr Soc. 2018:66:1451-4.

38. Moyet J, Deschasse G, Marquant B, Mertl P, Bloch F. Which is the optimal orthogeriatric care model to prevent mortality of elderly subjects post hip fractures? A systematic review and meta-analysis based on current clinical practice. Int Orthop. 2018; https://doi.org/10.1007/s00264-018-3928-5. Ahead of print.

39. Andrew MK. Frailty and social vulnerability. Interdiscip Top Gerontol Geriatr. 2015:41:186-95.
Ready to submit your research? Choose BMC and benefit from:

- fast, convenient online submission

- thorough peer review by experienced researchers in your field

- rapid publication on acceptance

- support for research data, including large and complex data types

- gold Open Access which fosters wider collaboration and increased citations

- maximum visibility for your research: over $100 \mathrm{M}$ website views per year

At BMC, research is always in progress.

Learn more biomedcentral.com/submissions 